\title{
HYDROLOGICAL INVESTIGATIONS INTO THE PROBLEM OF THE MASS BALANCE OF THE KANGERDLUGSSUAQ GLETSCHER
}

THE final paper of the second session was read by Dr. F. Nusser and described work on the Kangerdlugssuaq Gletscher that will be published, together with the other results of Expédition Internationale Glaciologique au Groenland (E.G.I.G.) in Meddelelser om Grønland; only a summary is included here. The main aim of the work was to use hydrographic methods to try to establish the amount of melt water running off from one of the glaciers draining the Greenland Ice Sheet and terminating in a fjord. The glacier chosen, Kangerdlugssuaq Gletscher, discharges into the Kangerdlugssuaq Fjord, and was one of the focal points of the coastal glaciological programme of E.G.I.G.

The method consisted of making a general hydrographic survey of the fjord. Apart from the glacier there is no other significant inflow of water which could affect the results, and the regular shape of the fjord facilitates dynamical calculations. Equally important in the survey work, the iceberg productivity is not as great as for the neighbouring Rink Gletscher, though even in Kangerdlugssuaq Fjord there were enough icebergs to prevent the use of anchored current meters. The bottom of the fjord was fully investigated along three longitudinal sections and 20 cross-sections, and the hydrographic conditions were measured by 104 hydrographic series, 4 anchoring stations, 2 normal gauges and one deep-sea gauge.

Unfortunately it turned out that the method was not accurate enough to determine the melt water in comparison with a tidal range of $2 \mathrm{~m}$. There seem to be two possible ways of attempting to measure melt water other than by conventional hydrographic means, one would be to use a dye such as rhodamine to identify the places where melt water flows out and then to use a special method to estimate the quantity. The other method would be more difficult, it consists of measuring the melt water from all the active glaciers in the area by a general hydrographic survey off the coasts of Baffin Bay.

Finally Dr. Nusser reported an experiment conducted by himself and Professor R. Haefeli to measure the iceberg productivity of Kangerdlugssuaq Gletscher. This was undertaken, although not originally on their programme, because for various reasons the geodesy group had been unable to do it during r 959 . They used a Zeiss theodolite, but were hampered by the lack of any camping or cooking equipment. The method adopted was to use a Ioo m. base line on an old moraine ridge to survey the velocity of eight points over the glacier, which, in this region, is $4.4 \mathrm{~km}$. wide and heavily crevassed. In $4 \mathrm{I} \mathrm{hr}$, eleven series of measurements were taken and the velocities of the points were calculated. The maximum velocity found was $5 \mathrm{~m}$./day and the minimum was $3.2 \mathrm{~m}$./day. If we assume that these velocities are the mean annual velocities, which may be the case for an ice sheet, then we can deduce the average iceberg production; it is $\mathrm{I} \cdot 64 \mathrm{~km} .3 / \mathrm{yr}$. This corresponds to a loss of water at the rate of $45 \mathrm{~m} .3 / \mathrm{sec}$. Professor A. Bauer has estimated the ablation from the surface of the glacier to be about $\mathrm{I}$ m. of water equivalent for the whole ablation season. Assuming this to last 120 days, the run-off should be about I $_{1} 6 \mathrm{~m} \cdot 3 / \mathrm{sec}$. from the $\mathrm{I}, 200 \mathrm{~km} .^{2}$ of glacier surface. It thus seems from these calculations that more water is released by surface melting than by icebergs, though of course we do not know how much of this surface melt water finds its way into the fjord and how much gets refrozen inside the glacier; this is what one might hope to determine by the hydrographic measurement of the melt water entering the fjord.

\section{DISCUSSION OF DR. F. NUSSER'S PAPER}

DR. B. FRISTRUP: I have to confess that I am partly responsible for choosing that glacier for this special purpose; my only excuse is that I knew the iceberg production of that glacier was rather small compared with the Rink Gletscher or some of the other glaciers, and so it is a 
rather safe fjord to work in. But, as Dr. Nusser has told us, the hydrographical results are rather poor.

Dr. Nusser: The Kangerdlugssuaq Fjord has only few icebergs, but even if you had a fjord without icebergs, the hydrographical instruments made for rough seas would not be sensitive enough to find such small quantities of water. We must develop instruments which are more sensitive, but which can have lower strength since they do not have to withstand the great pressure of water that we get in the open sea.

Professor S. E. Hollingworth: The cross-section you showed of the change in salinity of the water near the ice front is strongly asymmetric, and it seems to me that the lowest density water is coming from one side. Does that correspond to the convex side of the glacier? That side might be more crevassed, and much more water might therefore come out there.

Dr. Nusser: The Kangerdlugssuaq Gletscher has a rather irregular end, it does not run straight across the fjord, but rather has a tongue sticking out on one side. It is difficult to say whether this is water from under the glacier or from icebergs lying near this glacier tongue.

Dr. G. DE Q. RoBin: Have you made an estimate of what water flow in the fjord you would expect to be able to detect with your hydrographical methods?

Dr. Nusser: No, our idea was first to find the hydrographic conditions of the fjord and the size of the tides. Unfortunately we could not fix the tidal currents because the current meters were turned over by icebergs, but it would be possible if the amount was not too small. We also ran into trouble because the mid-point of the tidal swing lay out in Baffin Bay. When we started we hoped we would find a ridge, as is usual across the mouth of a fjord, but there is no ridge in this fjord - the water has a depth of $500 \mathrm{~m}$.!

Mr. W. Campbell: We have developed a device for use under the Arctic sea ice for measuring very small water velocities. It puts out a drop of oil into deep water, and this is photographed at certain intervals. Perhaps this would help in this problem. It is very exact.

Mr. A. WeIDick: I would like to comment on the mass balance of the Kangerdlugssuaq Gletscher. If we compare the records of this glacier from the r87o's up to the Greenland Institute map from the I930's, we can see that there has been very little recession of the glacier front. 